\title{
Research on Relationship Between Buyer Behaviour and Customer Delight Towards FMCG Environment Friendly Products
}

\author{
A.Vinoth, K.Ramprabha
}

\begin{abstract}
The concept of customer satisfaction is studied with their behaviour and suggestions given for ready for action. Since all producers in the market place is trying to make their buyers happy and satisfied, it becomes very important for the business to delight its customers.This study about the connection between the customer happiness or delight and buyer behavior towards environment friendly products. Correlation is used for this study. It's found that there is positive relation between them.
\end{abstract}

Key words: buyer behavior, customer delight, relationship, correlation, environmentally friendly.

\section{INTRODUCTION}

Buyer behavior can be considered as acomponent of management theorythatexamines and analyses the shopping habits of the people and/or groups that are primarily used for marketing purpose. This analysis includes an examination of decision making, perception and satisfaction of the shoppers. Buyer behaviour involves the psychological and sociological actions which the shoppers carry out to getthe goods and services and find satisfaction from them. Buyer behavior is very compound and vibrant, and therefore, constantly varying; the store managements should need to bend with thesemodifications otherwise the market may be lost.

\section{CUSTOMER DELIGHT}

It is the job of the sales and promotion department of the business to usethe instances of customer delight to a company's advantage by requesting referrals and by getting testimonials from delighted shopperswhich will eventually facilitate new customer.

\section{REVIEWS OF LITRATURE:}

ZainuddinYuserrie Bin (2011)stated that all the retailer actions are intended to create and assist any exchanges that are anticipated to fulfill the consumer needs or wants, where the fulfillment of these needs or wants eventually have aninfluence on the natural environment. His study has identified the influence of media over the purchase intention of lead-free electronic products (green electronics) among college professors. His results have showed that exposure to media had a significant positive influence on the college professors' purchase intentions.

Evans and Burns, (2007)piloted three empirical researches to study product related delight. The authors theorized delight, as the experience of theshoppers when their anticipations are unexpectedlyconfirmed. Also,it is defined that delight as theleeway lead of satisfaction which is categorized by pleasure. From the research they determined that delight is anemotion of consumption.

Wang (2011)piloted a research on unconnected supporting service quality on consumer delight, satisfaction and repurchase intentions in a field experimentation with PG students in managementin a university located in South China. He identified that serviceis not considerablyrelated to escalatingprocess of the core service, rather,it provides an extra benefit to improve the attractiveness of the core service offered to the consumers. He also recognizedthat essential service as the crucial value that the service product offers and it is the primary reason for the consumer purchase. In addition to that, a business must offer unanticipated value in anoptimistic way like delivering valued supporting services that is unrelated to the core service. The happening of delight requires more than simply gaining satisfaction; henceforth resulting in a positive disconfirmation delight would be produced.

\section{RESEARCH METHODOLOGY:}

Sample Area: Chennai / Sample Size: 509 / Sampling Technique: Convenient sampling / Statics Tools used: Correlation and Descriptive.

\section{HYPOTHESIS OF THE STUDY:}

H0-1: There is no significant relationship between customer delight and buyer behavior.

H0-2: There is no significant relationship between customer delight and buyer behavior

VI. ANALYSIS\& INTERPRETATION \& RESULTS LEVEL OF CUSTOMER DELIGHT

\footnotetext{
Revised Manuscript Received on September 10, 2019.

Dr.A.Vinoth, Assistant Professor, Department of Business Administration,Vels Institute of Science, Technology and Advanced Studies (VISTAS), Chennai, Tamil Nadu, India

(email: avinubemba@gmail.com)

Dr.K.Ramprabha, Department of Business Administration,VISTAS Chennai, Tamil Nadu, India
} 
Research on Relationship Between Buyer Behaviour and Customer Delight Towards FMCG Environment Friendly Products

Table 1: Distribution of Respondents Among Level of Consumer Delight

\begin{tabular}{|c|c|c|c|c|c|c|c|c|c|c|c|c|}
\hline \multirow[b]{3}{*}{ Level } & \multicolumn{10}{|c|}{ Customer Delight Dimensions } & \multirow{3}{*}{$\begin{array}{c}\text { Overall } \\
\text { customer } \\
\text { delight } \\
\mathrm{N} \\
\text { VALUE }\end{array}$} & \\
\hline & \multicolumn{2}{|c|}{ Justice } & \multicolumn{2}{|c|}{ Esteem } & \multicolumn{2}{|c|}{ Security } & \multicolumn{2}{|c|}{ Trust } & \multicolumn{2}{|c|}{ Variety } & & \\
\hline & $\begin{array}{c}\mathbf{N} \\
\text { VALUE }\end{array}$ & PERCENT & $\begin{array}{c}\mathbf{N} \\
\text { VALUE }\end{array}$ & PERCENT & $\begin{array}{c}\mathbf{N} \\
\text { VALUE }\end{array}$ & PERCENT & $\begin{array}{c}\mathbf{N} \\
\text { VALUE }\end{array}$ & PERCENT & $\begin{array}{c}\mathbf{N} \\
\text { VALUE }\end{array}$ & PERCENT & & PERCENT \\
\hline Low & 69 & 13.6 & 89 & 17.5 & 64 & 12.6 & 98 & 19.3 & 119 & 23.4 & & \\
\hline Medium & 245 & 48.1 & 171 & 33.6 & 357 & 70.1 & 318 & 62.5 & 157 & 30.8 & & \\
\hline High & 195 & 38.3 & 249 & 48.9 & 88 & 17.3 & 93 & 18.3 & 233 & 45.8 & 509 & 100.0 \\
\hline Total & 509 & 100.0 & 509 & 100.0 & 509 & 100.0 & 509 & 100.0 & 509 & 100.0 & 509 & 100.0 \\
\hline
\end{tabular}

It is found that the overall customer delight is high among 100 percent of the respondents and it is not found low or moderate with any of the respondents. Observation from the result shows that 48.1 percent of the respondents perceive medium level of justice and 38.3 percent of the respondents perceive high level of justice. It is found that 48.9 percent of the respondents perceive high level of esteem and 33.6 percent of the respondents perceive medium level of esteem. Security is at moderate level with 70.1 percent of the respondents and 17.3 percent of the respondents perceive high level of security. Trust is also at the moderate level with 62.5 percent of the respondents and it is also noted that 19.3 percent of the respondents have only low level of trust. Variety is at high level with 45.8 percent of the respondents and 30.8 percent of the respondents perceive high level of variety. The result revealed that all the customer delight dimensions are distributed at moderate level among majority of the respondents. It is also found 23.4 percent of the respondent's perception low towards variety among all dimensions of customer delight. Among the customer delight dimensions 70.1 percent of the respondent's perception is high towards security and 48.9 percent of the respondent's perception is high towards esteem.

Table - 2:Relationship between Buyer Behavior and Customer Delight

\begin{tabular}{|c|c|c|c|c|c|c|c|c|c|c|c|c|}
\hline \multirow[b]{3}{*}{ Variables } & \multicolumn{10}{|c|}{ Customer Delight Dimensions } & \multirow{2}{*}{\multicolumn{2}{|c|}{$\begin{array}{c}\text { Overall customer } \\
\text { delight }\end{array}$}} \\
\hline & \multicolumn{2}{|c|}{ Justice } & \multicolumn{2}{|c|}{ Esteem } & \multicolumn{2}{|c|}{ Security } & \multicolumn{2}{|c|}{ Trust } & \multicolumn{2}{|c|}{ Variety } & & \\
\hline & r-value & p-value & r-value & p-value & r-value & p-value & r-value & p-value & r-value & p-value & r-value & p-value \\
\hline Decision making & $0.181^{* *}$ & 0.000 & $0.218^{* * *}$ & 0.000 & $0.157^{* *}$ & 0.000 & $0.121^{* *}$ & 0.006 & $0.250^{* *}$ & 0.000 & $0.279^{* *}$ & 0.000 \\
\hline $\begin{array}{l}\text { Green customer } \\
\text { satisfaction }\end{array}$ & $0.224^{* *}$ & 0.000 & 0.126 & 0.004 & $0.181^{* *}$ & 0.000 & $0.095^{*}$ & 0.032 & $0.164^{* *}$ & 0.000 & $0.247^{* *}$ & 0.000 \\
\hline Perception & $0.303^{* *}$ & 0.000 & $0.152^{* *}$ & 0.001 & $0.212^{* *}$ & 0.000 & $0.105^{*}$ & 0.017 & $0.166^{\text {** }}$ & 0.000 & $0.298^{* *}$ & 0.000 \\
\hline $\begin{array}{c}\text { Overall buyer } \\
\text { behavior dimensions }\end{array}$ & $0.304^{* *}$ & 0.000 & $0.186^{* *}$ & 0.000 & $0.227^{* *}$ & 0.000 & $0.133^{* *}$ & 0.000 & $0.219^{* *}$ & 0.000 & $0.334^{* *}$ & 0.000 \\
\hline
\end{tabular}

** Correlation is significant at the 0.01 level (2-tailed).

*Correlation is significant at the 0.05 level (2-tailed).

Table 2 reveals the correlation between buyer behavior and customer delight.

H0-4.21.1: There is no significant relation between overall buyer behavior and its dimensions and overall customer delight and its dimensions.

To test the stated hypothesis Pearson's coefficient correlation is applied. The r-value 0.304 shows that there is positive correlation between justice and overall buyer behavior and also significant at 5 percent level. Esteem perceived by the respondents has positive correlation with overall buyer behavior of the respondents with r-value 0.186 it is also significant at 5 percent level.

The r-value 0.227 shows that there is positive correlation between security and overall buyer behavior at 5 percent level significant. Customer delight dimensions trust and varieties also have positive correlation with overall buyer behavior of the respondents with r-values 0.133 and 0.219 . It is also observed from the result $r$-value 0.126 and customer satisfaction does not correlate with esteem. It is also observed from the result that the customer satisfaction and perception is correlate with trust with r-values 0.095 and 0.105 and is also significant at one percent level. All dimensions of Buyer behavior such as decision making, customer satisfaction and perception has positive correlation with justice, security and variety of the customer delight dimensions.

\section{FINDINGS OF THE STUDY:}

It is found that 100 percent of the respondents have customer delight level and none of them have low and medium level customer delight.

Buyer behavior dimension such as customer satisfaction does not correlate with one of the customer delight dimensions such as esteem. 
There is a positive correlation between overall buyer behavior and its dimensions such as decision making and perception with overall customer delight and its dimensions such as justice, esteem, security, trust and variety. It is also found that customer satisfaction correlate with all four dimensions of customer delight except esteem.

\section{CONCLUSION:}

This research concludes that all respondents has high level of customer delight towards green products andit has positive relationship with buyer behavior that means if customer delight increase buyer purchase behavior also will increase.

\section{REFERENCES:}

1. Violetasima (2013). "B2b Green Marketing In Romania", Economic Insights - Trends And Challenges, Vol. 2, No.1, Pp.151-158, 2013.

2. Evans, R.I. (1989), Albert Bandura; the Man and His Ideas: A Dialogue, New York: Praeger, 1989, Pp. 3-22.

3. Berman,B. (2005).How to delight yours customers California Management Review,48(1):pp.129-51.

4. Kwong,k.,k.\&you,O.H.,M.(2002). Theconceptualisation of customer delight; A research frame work.Asia Pacific Management Review, 7(2); 255-265 